\title{
Rediscovering Apprenticeship
}

\author{
Michael H. Hoeflich*
}

The crisis in legal education-or, perhaps, better put, the crisis for law students-has found its way into the national media. The New York Times, for instance, has published many stories about the financial crisis faced by law graduates unable to find legal jobs or legal jobs paying a living wage. ${ }^{1}$ This spring, a law professor at Washington University in St. Louis, Brian Tamanaha, published a scathing indictment of American law schools, Failing Law Schools. ${ }^{2}$ The focus of media articles has been on the less-than-honest ways in which many law schools have inducedif not seduced-potential students to attend. ${ }^{3}$ Professor Tamanaha's book looks at these methods, as well as structural problems in American legal education, in greater detail. This current crisis is extremely distressing, particularly for those of us who have devoted our professional careers to schools of legal education. Last year, only about two-thirds of American law graduates managed to find legal jobs, and many of these carried salaries that left graduates with insufficient funds to pay off their staggering debt loads. ${ }^{4}$

The good news for Kansas law students and lawyers is that neither Washburn University nor the University of Kansas indulged in the kinds of deceptive practices that law schools in other states engaged in. Law school tuitions in Kansas are far below the \$50,000 charged by many private schools. Thus, the debt burden carried by many Kansas law graduates is far smaller than that of those who attend private schools in other states. Placement numbers are better in Kansas, too, but still far \footnotetext{
Law.

John H. and John M. Kane Distinguished Professor of Law, University of Kansas School of

1. E.g., David Segal, Is Law School a Losing Game?, N.Y. TiMES, Jan. 8, 2011, at BU 1.

2. BRian Z. TAMANAha, Failing LaW Schools (John M. Conley \& Lyann Mather, eds., 2012).

3. See, e.g., INSIDE THE LAW SCHOOL SCAM (Aug. 23, 2012, 2:37 PM), www.insidethelaw schoolscam.blogspot.com.

4. This figure comes from NALP, the Association for Legal Career Professionals. Only $65.4 \%$ of the graduating class of 2011 founds jobs for which a J.D. was required. Class of 2011 Has Lowest Employment Rate Since Class of 1994, NALP Bulletin (July 2010), www.nalp.org /0712research.
} 
from the ideal $100 \%$. On the other hand, while the average debt burden of Kansas law graduates does not approach the stratospheric national average, it is still high: graduates from the KU Law School have an average of $\$ 67,598$ of debt and Washburn graduates on average are burdened by $\$ 79,665$ in debt. ${ }^{5}$ This is crippling for those who cannot find legal jobs within nine months of graduation. Even for those who are fortunate enough to find legal jobs, the debt burden many face is still too high and will cause them financial problems for many years after graduation. It may also limit their ability to take lower paying jobs, for example, jobs in government or with legal aid agencies. The response of our law schools has been to lower class sizes. Obviously, this reduces the competition for the decreasing number of legal jobs available to graduates. Our law schools have also begun to do more to pursue legal jobs outside of the private sector, such as with the Judge Advocate General's Corps, but, in my opinion, this is not enough. The debt burden young law graduates face combined with the changing shape of the legal employment market is unlikely to revert back to that of the 1980s, when law schools were still cheap and jobs were plentiful, and requires a far more radical solution than simply limiting class size. ${ }^{6}$ The time has come for the organized bar and the Supreme Court to consider another solution-reinstituting a version of the traditional method of legal education: apprenticeship.

Professor Tamanaha argues in his book that the great structural failing of American legal education is that there is no differentiation in legal education while there is extreme differentiation in the legal profession. $^{7}$ What he means by this is simple. The legal profession is not organized around a single business model. Lawyers work in a wide range of professional settings. Lawyers in private practice may work in corporate mega firms, in small to medium size general practice firms, in small specialist boutique firms, or in solo practice. In the public sector, lawyers may work for the federal government, state or local government,

5. Whose Graduates Have the Most Debt?, U.S. News \& WORLD RePORT 6, 7, gradschools.usnews.rankingandreviews.com/best-graduate-schools/top-law-schools/grad-debt-rankings/ (last visited Sept. 6, 2012).

6. See Jean Braucher, Repaying Debt for Law School: Federal Programs Make It Doable, Not Easy, CREDIT SLIPS (July 16, 2012, 8:00 PM), http://www.creditslips.org/creditslips/2012/07 /debt-for-law-school-you-wont-get-rich-but-federal-programs-make-it-doable.html (discussing the financial problems graduates with debt face).

7. TAMANAHA, supra note 2, at 173-74. 
or the military. One of the great advantages of a law license is that it permits lawyers to work in a remarkable range of professional settings.

Given the diversity of legal jobs, it is, therefore, quite strange that legal education in the United States today is so rigidly built around a single model. ${ }^{8}$ Since the early twentieth century in most states, including Kansas, law schools in collaboration with the organized bar and judiciary have recognized only a single path to a law license: graduation from an accredited law school. Law schools accredited by the American Bar Association (ABA) typically require that students complete an undergraduate degree plus three years of law school - a total of seven years of higher education — to be eligible for the bar examination. ${ }^{9}$ Some law schools allow students to reduce these seven years to six by enrolling in an approved " $3-3$ " program. ${ }^{10}$ But these six years of expensive university education is the minimum that any would-be lawyer must undergo and pay for to qualify to take the Kansas bar examination. I would suggest - much to some of my colleagues' horror - that this is still too long and costly a path to the bar for many students. Instead, I believe that for many students a four-year undergraduate program followed by three semesters at law school and a period of apprenticeship in a lawyer's office or judge's chambers would more than suffice. ${ }^{11}$

8. TAMANAHA, supra note 2, at 172; Michael H. Hoeflich, The Bloomington Law School, in Property LAW AND Legal EdUCATION, EsSAYs IN HONOR OF JoHn E. CRIBbet 203-17 (1988).

9. E.g., KAN. CT. R. 706. A few law schools permit a more accelerated graduation by running twelve-month programs. For example, KU has a "summer start" program that involves an equivalent of six semesters and costs the same as six semesters per credit hour. The Summer Start Advantage, www.law.ku.edu/summerstart (last visited Dec. 13, 2012). See also 2012-2013 ABA STANDARDS AND RULES OF PROCEDURE FOR APPROVAL OF LAW SCHOOLS 22, www.american bar.org/content/dam/aba/publications/misc/legal_education/Standards/2012_2013_aba_standards_an d_rules.authcheckdam.pdf (providing that under Standard 304(b) and (c), law schools require, as a condition of graduation, successful completion of a course of study in residence of not fewer than 58,000 minutes of instruction in no fewer than 24 months and no longer than 84 months).

10. The typical " $3-3$ " program is one in which a student spends three years in an undergraduate program and then begins her first year of law school instead of completing a standard fourth undergraduate year. After successfully completing her first year of law school, the student earns her bachelor's degree. See, e.g., 3 + 3 Law Program with Albany Law School, U. OF Albany, http://www.albany.edu/advisement/albany_law_3+3.shtml (last visited Aug. 23, 2012); 3-3 Applicants, CREIGHTON U. SCH. OF L., www.creighton.edu/law/admissions/applyingtocreightonlaw/ 33applicants/index.php (last visited Aug. 23, 2012).

11. Certainly, the idea of reviving apprenticeship is not mine alone. Professor Tamanaha would seem to generally agree with the revival of an apprenticeship system in some form, though he would seem to prefer that this be controlled and managed by law schools. See TAMANAHA, supra note 2, at 175-76. Judge José Cabranes, in a speech to the American Association by Law Schools in January 2012, proposed that the current three-year law school curriculum be replaced by a two-year “core” program and a one-year apprenticeship. See Paul L. Caron, Judge Cabranes' Three-Part Prescription for Law Schools, TAX PROF BLOG (Jan. 7, 2012), http://taxprof.typepad.com 
By permitting students to qualify to sit for the bar examination with only three semesters at law school, we could save students a substantial sum of money. For example, at KU, using current tuition and fee data, eliminating three semesters of law school would save a student \$27,995 in tuition and fees. ${ }^{12}$ After factoring in living costs in Lawrence, a student would save $\$ 52,082 .^{13}$ Further, many students who live in less expensive towns during their apprenticeships will have even lower living costs. In addition, I believe that many students would be as well or better prepared for a legal career than they are currently under our mandated seven years of undergraduate and law school training.

In fact, the undifferentiated nature of American legal education is a relatively recent phenomenon, although the push in favor of such a system by university-affiliated law schools is much older. From precolonial times to the early twentieth century, Americans who wanted to become lawyers had multiple ways in which to do so. ${ }^{14}$ The most common method, by far, until the late nineteenth century, was "reading the law," i.e., serving as an apprentice in a law office for an extended period of time. ${ }^{15}$ During the early nineteenth century two new forms of legal education arose, law schools taught by eminent judges and lawyers, such as the Litchfield Law School in Litchfield, Connecticut, and university-affiliated law schools such as the Dane Law School at Harvard and the Transylvania University Law School in Kentucky. ${ }^{16}$ Interestingly, students who attended either type of these early law schools were not expected to spend three years in attendance, nor was it assumed that they would practice law immediately upon graduation. The value of law school attendance was that students could get a more

/taxprof_blog/2012/01/judge-.html. I do not agree with Judge Cabranes' harsh remarks about interdisciplinary scholarship and globalization, although, as I state below, these subjects are not necessary to every law student's education. Professor Samuel Estreicher discusses Judge Cabranes' speech (although he rejects the need for apprenticeship at all) is his essay The Roosevelt-Cardozo Way: The Case for Bar Eligibility After Two Years of Law School, available at http://lawprofessors. typepad.com/files/estreicher-article-1.pdf.

12. How to Apply, KU SCH. OF L., www.law.ku.edu/apply (last visited Nov. 26, 2012) (providing that Kansas resident tuition is $\$ 612.95$ per credit hour and each student is required to pay an annual campus fee of \$888.00).

13. Id. (providing average room and board, personal, and transportation expenses for a law student living in Lawrence).

14. See generally, Michael H. HoEflich, THE GladSOME Light OF JURISPRUdENCE (1988); Hoeflich, supra note 8, at 203-17.

15. On colonial apprenticeship, see Paul M. Hamlin, Legal Education in Colonial NeW YORK (1939).

16. Hoeflich, supra note 8, at 2-7. 
systematic - the contemporary term was "scientific"-legal education at a law school. ${ }^{17}$ There was no practical training, with the exception of moot court, but practical training was not necessary because those who attended law school were still expected to read law in a law office before being admitted to the bar. ${ }^{18}$ At many law schools, lectures were scheduled so that students could work as law clerks in law offices for part of the day.

The twentieth century saw the beginnings of an organized assault on non-university-affiliated law schools and legal apprenticeships led by university-affiliated law schools, and the ABA and the American Association of Law Schools. By the mid-1920s, the campaign was over and most states required graduation from an ABA accredited law school as a prerequisite for taking the bar examination and being admitted to practice law. ${ }^{19}$ It is not necessary to believe, as Professor Tamanaha appears to, that this was a nefarious plot or that it did not work well. Even good ideas may become outmoded. For most of the twentieth century, legal education as it now exists, i.e., three years at a universityaffiliated law school, worked well. This was because it was inexpensive and, in fact, differentiated to a large extent. Differentiation came not through different educational models but rather through the split among law schools between elite private schools, whose graduates were destined to work in elite law firms or the federal government, and public law schools whose graduates were destined to work in smaller firms, in smaller cities and towns, and for state government. A second form of differentiation was the type of scholarship and research done at elite versus public law schools. At national elite law schools like Harvard, Yale, and Columbia, much, but not all, of the faculty scholarship was what might be called "high" scholarship. At Yale, for instance, many of the faculty engaged in complex jurisprudential debates about the sources of law-a debate that gave rise to the "realist movement" in jurisprudence. But at most public schools, faculty scholarship was more doctrinal and focused on assisting judges and lawyers in their states and regions.

17. Daniel Mayes, An Address to the Students of Law in Transylvania University (1834), in THE GLADSOME LIGHT OF JURISPRUDENCE 145-64 (1988).

18. On early moot court programs at American law schools, see generally Michael H. Hoeflich, Plus ca Change, Plus C'est la Meme Chose: The Integration of Theory \& Practice in Legal Education, 66 TEMP. L. REV. 123 (1993).

19. See generally, Hoeflich, supra note 8 . 
Over the past quarter century, the de facto differentiation that existed during earlier periods began to disappear. Even public law schools began to raise tuition to levels that most students could not pay without taking on significant debt. In many cases, such as at KU, the law school does not have the independent ability to set a different tuition-it is set by the university's central administration. ${ }^{20}$ Further, for a variety of reasons, faculties at public universities began to emulate their brethren at elite private universities, abandoning doctrinal scholarship and scholarship intended to help the practicing bar for what I call high scholarship. $^{21}$ This has not been universal. For instance, Bob Casad, John Peck, Webb Hecker, Dennis Prater, and Lu Mulligan, among others, at KU have devoted much of their professional writing to Kansas law. ${ }^{22}$ Much the same can be said for many faculty at Washburn, including Linda Elrod, whose work has focused primarily on Kansas family law, ${ }^{23}$ and Jim Concannon, who serves as a Uniform Law Commissioner. ${ }^{24}$ But many state law schools in the past quarter century have put an emphasis on faculty who are primarily interested in high scholarship and who are more directed to the national conversation among jurists and other law professors. The result is that even students at small public law schools receive a legal education similar to that which they would receive at a Harvard or Yale-and they think that this is a good thing. For some it is. For many, in my opinion, it is not. For many students, the truth is that they are paying too much for information and training that they do not need and will not use. In short, the current system of legal education in the United States, including in Kansas, does

20. And this leads, inevitably to the temptation to impose high tuition increases on entering law students. In 2012, in-state tuition at the University of Kansas increased $4.9 \%$ and out-of-state tuition increased by 5\%. See Scott Rothschild, KU Tuition and Fees Going Up; Admission Standards Getting More Stringent, L.J. WORLD, June 20, 2012, www2.ljworld.com/news/2012/jun/20/ statehouse-live-ku-tuition-and-fees-going/.

21. Professor Tamanaha seems to be quite bothered by this trend. TAMANAHA, supra note 2, at 54-61. It is interesting to note, however, that Professor Tamanaha teaches at an elite private school, namely Washington University in St. Louis, and is an extremely successful scholar of legal theory and jurisprudence, quintessentially high scholarly subjects. See Bryan Z. Tamanaha, Faculty Profiles, WASH. U. L., law.wustl.edu/faculty_profiles/profiles.aspx?id=7287 (last visited Oct. 1, 2012).

22. See, e.g., Edwin W. Hecker, Jr., The Kansas Business Entity Transactions Act, J. KAN. B. Assoc. Sept. 2011 at 21; Dennis D. Prater, Res Gestae Raises Its Ugly Head, J. KAN. B. Assoc. Oct. 1996 at 24.

23. See Linda Henry Elrod: Richard S. Righter Distinguished Professor of Law, WASHBURN U. SCH. OF L., http://wasburnlaw.edu/faculty/elrod-linda.php (last visited Oct. 1, 2012).

24. See James M. Concannon: Distinguished Professor of Law, WASHBURN U. SCH. OF L., http://wasburnlaw.edu/faculty/concannon-james.php (last visited Oct. 1, 2012). 
not best serve all those who want to become lawyers. Individuals who want a traditional, three-year, broad and deep legal education are well served by the current system, especially those who believe that such an education is worth its cost. But for students with different goals, such as those who want to practice in Kansas as solo practitioners or in small general practice firms in smaller towns or who want to devote their careers to legal aid, the organized bar needs to seriously consider offering an alternative to the traditional three-year model.

Many law professors and others interested in legal education argue that the best way to serve such individuals is to increase the number of practice-oriented and clinical courses within the traditional three-year law school model. As someone who has taught clinical courses and currently teaches a practice management class aimed at students who want to be solo practitioners or practice in smaller offices, I certainly think that clinical and practice-oriented courses should be an important part of every student's legal education. However, I do not think that adding more of these courses is a full solution to the problem for three major reasons. First, most law professors do not have the experience to teach such courses. ${ }^{25}$ Second, clinical and practice-oriented courses must have small enrollments. Thus, clinical law teachers teach a very small number of students each semester. This means that any increase in the number of such courses will significantly increase the cost of a traditional legal education. Most law schools simply cannot afford to expand clinical programs to serve significantly larger numbers of students without raising tuition to cover the increased cost. Thus, such an expansion of clinical courses may increase the debt burden that so many current law graduates bear. Even at KU and Washburn, where the average debt load is low by national standards, the individual burden is too high for those graduates who either choose lower paying employment or are forced into such employment by market conditions. Thus, I strongly believe that the best solution for Kansas is to adopt a second path to bar admission: a combination of three semesters at law school and a required period of at least eighteen months of apprenticeship.

At present seven jurisdictions permit law students to "read for the bar”: California, Maine, New York, Vermont, Virginia, Washington, and Wyoming. ${ }^{26}$ California requires a minimum of four years of law office

25. It is quite rare for law schools to hire entry-level law professors who have more than a few years of practical experience.

26. NAT'L CONF. OF BAR EXAMiners \& AM. BAR Ass'N SECTION OF LEgAL EdUC. \& 
study. ${ }^{27}$ Maine requires that bar applicants have completed two-thirds of the credits required at an ABA accredited law school plus one year of law office study. ${ }^{28}$ New York requires one year at an ABA accredited law school plus law office study, but does not specify the number of years a student must spend in a law office. ${ }^{29}$ Wyoming requires that bar applicants spend at least three years in a combination of law office study and at an ABA accredited law school with the permission of the bar examiners. ${ }^{30}$ Vermont requires four years of law office study. ${ }^{31}$ Virginia requires a minimum of three calendar years of law office study with an approved law reader supervisor and permission of the Bar Examiners. ${ }^{32}$

Interestingly, Vermont requires a three-month period of law office study of all bar applicants, including those with a degree from a threeyear, ABA accredited law school, which may be completed after completion of the first year of law school. ${ }^{33}$ Arguments against a required period of apprenticeship like the Vermont system tend to focus on the burden such a requirement places on the practicing bar as well as the fear that the apprenticeship system would not provide a consistently good experience for all apprentices. Vermont is able to make the system work because it is a small bar and the bar and judiciary maintain close oversight of the program. In New York, for example, where the bar is simply too large to initiate a mandatory apprenticeship system, the quality of apprentice education is left to market forces, i.e., would-be lawyers will seek out only good "apprentice masters" because that is the only way they will learn enough to pass a difficult bar examination. I believe that Kansas is a small enough bar to be able to adopt a voluntary apprenticeship system like New York that, with appropriate oversight and a serious bar examination, will work well.

I also believe that like New York, Maine, and Wyoming, Kansas should require every bar applicant to spend some time at an accredited

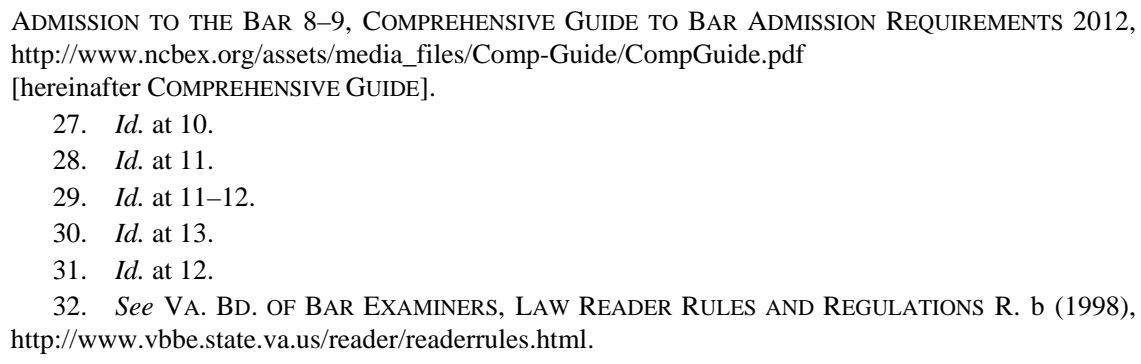

33. COMPREHENSIVE GUIDE, supra note 26, at 22. 
law school. Professor Tamanaha recommends in his book that all bar applicants should spend two years at an accredited law school. ${ }^{34}$ How much time one requires is a very subjective decision. My own thinking is that a modified Wyoming model would work best in Kansas. ${ }^{35}$ I would suggest that every bar applicant should spend at least three semesters at a traditional law school. I have arrived at that number through a simple reasoning process. Every lawyer should have systematic instruction in what are now basic first year courses at virtually every American law school because these are the building blocks upon which all legal knowledge is formed. Further, traditional law professors excel at teaching these basic courses in which basic legal reasoning and case analysis are paramount. Second, traditional law schools teach legal research skills during the first year and these, too, should be taught systematically to beginning law students. Third, the first year of law school tends to be the time when law students can determine whether they are personally suited to the law and legal thinking, and, if they are not, they can look for another profession more suited to their talents. For these reasons, every would-be lawyer should go through the traditional first year program at a law school.

I also believe that every law student should spend at least one more semester in a law school setting. This is necessary because students will need at least one more semester to study those courses that, although not included in the first year curriculum, are basic to every lawyer's practice and are tested on the bar examination. In Kansas these include basic corporation law, trusts and estates, and professional responsibility. Beyond these three semesters, however, I would let law students choose whether to stay in law school or enter an apprenticeship program. Some students might, for instance, choose to spend an additional semester in law school and study courses such as agricultural law, water law, and land use. They would then be required to spend only twelve months as an apprentice. Others, as I have mentioned, could stay the whole three years and be permitted to take the bar examination immediately after graduation. In effect, every law student would be required to devote three years to her legal education but could decide whether to spend one, two, or three semesters beyond the required three semesters in a

34. TAMANAHA, supra note 2, at 172-76.

35. See COMPREHENSIVE GUIDE, supra note 26, at 13 (explaining that Wyoming allows combination of "ABA-approved law school and time of study in the office of a member of the Wyoming State Bar (to total 3 years)” with the Board of Law Examiners approval). 
traditional law school setting according to their own interests and financial resources.

For my proposed system to work, several things would be required of the bar and the judiciary. First, a system for "accrediting" law offices for apprentice training would be necessary. The extent and content of such accrediting would be a task for the Supreme Court or its delegates to undertake. The Board of Bar Examiners would be an excellent agency to perform this task, perhaps in conjunction with the Commission on Continuing Legal Education. Alternatively, the Supreme Court could set up a separate commission on Legal Apprenticeship to exercise oversight on the apprenticeship system. Second, if Kansas were to adopt the system I propose, it would be extremely important for the Bar Examiners to ensure that the bar examination fulfill a gate keeping function and ensure that students who chose the apprenticeship model were fully qualified to enter the practice of law. Third, it would be crucial to establish rules about which lawyers may serve as supervisors of apprentices.

The Virginia Law Reader Rules \& Regulations might provide Kansas with a model for determining who can serve as a supervisor for apprentices. $^{36}$ In Virginia, to supervise a "law reader," i.e., a legal apprentice, a lawyer may act as a supervising attorney for only one law reader at a time. ${ }^{37}$ The lawyer must be either a member of the Virginia state bar who has been in active practice for at least ten of the preceding twelve years or a retired Virginia Circuit Court judge who served as such for at least ten years and has been retired for no more than five years preceding the beginning of her role as supervisor. ${ }^{38}$ In addition, a supervising lawyer may not have been subject to any disciplinary sanctions ${ }^{39}$ and must show that she is engaged in the general practice of law, ${ }^{40}$ that she has an adequate law library, ${ }^{41}$ and that she is a "capable" teacher. ${ }^{42}$ The one addition to these requirements Kansas might seriously consider is to permit active Kansas district judges with, perhaps, ten years of experience on the bench to serve as supervisors. This addition would provide assistance for many of our overworked district judges as

\footnotetext{
36. For the Virginia apprenticeship rules, see VA. BD. OF BAR EXAMINERS, supra note 32.

37. Id. Reg. 6 .

38. Id. R. b.1, Reg. 2.

39. Id. Reg. 8-2.B.

40. Id. R. b.2.

41. Id. R. b.4

42. Id. R. b.5.
} 
well as provide possible placements in rural counties where there might not be enough active lawyers available to serve as supervisors.

The Virginia requirements for supervisors may also provide guidelines as to the substantive content of the apprenticeship experience that should be required. The Virginia requirement that supervising lawyers be in the general practice of law is the most significant. ${ }^{43}$ Even though all bar applicants would be required to spend at least three semesters at a traditional law school, they would still not have the breadth of knowledge and experience we would want our future lawyers to have. If students were to spend their apprenticeship in a law office with a narrow specialty, e.g., medical malpractice litigation, they would not receive the breadth of knowledge they would need to pass the bar and practice law. Thus, it would be very important to ensure that the apprenticeship experience does, in fact, provide them with experience in a wide variety of matters, something that can only be accomplished in a general practice setting. Further, it would be important to ensure that the apprentices have practical experience in document drafting, legal research, general litigation, and client counseling. These experiences should be most likely in a general practice setting. The Supreme Court might also consider modifying Rule 719 , which permits law students to practice law within limitations under the supervision of a licensed attorney in law school clinical settings, ${ }^{44}$ to extend to apprentices working in law offices.

In the eighteenth and nineteenth centuries, apprentices paid their apprentice masters for the privilege to read law in their offices. I think that it would be perfectly appropriate for apprentices under a modern apprenticeship system in Kansas to pay their supervisors some amount to partially recompense the supervisors for the time and expenses involved in the supervision. On the other hand, these payments should be modest and subject to regulation by the Supreme Court.

The most essential element of a new apprenticeship model for legal education in Kansas will be the commitment of the bench and the bar. Once again, the Virginia Law Reader Rules \& Regulations can provide guidance. Regulation 1-2-B reads:

These regulations are premised on concepts of good faith and integrity. The Board cannot administer and supervise the readership on the daily

43. Id. R. b.4

44. KAN. CT. R. 719(a). 
basis expected in a traditional law school environment. The Board expects the Supervising Attorney and the reader to adhere to the letter and the spirit of the program. ${ }^{45}$

Any change as radical as the one I propose here will require extensive discussion and will face opposition. We have become accustomed to our current system of legal education over many decades, and change is never easy. On the other hand, I believe that many members of the bar and judiciary, as well as some law teachers, also realize that our current system is far from perfect. The current crisis in legal education is of sufficient magnitude to justify opening up the kind of discussion I am suggesting here, which I hope will result in changes that will benefit law students, the practicing bar and judiciary, and the people of Kansas.

45. VA. BD. OF BAR EXAMINERS, supra note 32, Reg. 1-2-B. 